\title{
Changes in the composition and structure at PET-waste processing into building materials
}

\author{
Natalya Fomina ${ }^{1, *}$, Olga Fedotova ${ }^{2}$ and Mikhail Polyanskiy ${ }^{1}$ \\ ${ }^{1}$ Yuri Gagarin State Technical University of Saratov, Department "Building Materials and \\ Technologies", Polytechnic St., 77, Saratov, Russia \\ ${ }^{2}$ Saratov State University, "Department of organic and bioorganic chemistry", Astrakhanskaya St., \\ 83, Saratov, Russia
}

\begin{abstract}
The results of studies of the composition and structure of polyethylene terephthalate in the process of thermomechanical processing of polymeric wastes as well as properties of waste products obtained on the basis of waste are presented. Methods of infrared spectroscopy, differential thermal analysis and thermogravimetry, as well as standard methods for manufacturing and testing the technical properties of samples of structural building products were used. As a result of thermomechanical processes during re-melting of polyethylene terephthalate waste, the number of hydroxyl groups in the polymer composition decreases, due to the possible cross-linking and polycondensation of macromolecules through terminal hydroxyl and unactivated carboxyl groups. In this case, conformational rearrangements take place in the structure of polyethylene terephthalate. When thermomechanical processing of secondary PET with rapid cooling of the melt, the temperature of the onset of subsequent melting decreases, which allows to reduce power consumption in melting-mixing units during the process of manufacturing construction products. Construction and technical properties of secondary PET as binder composite building materials allow to obtain potentially durable products with structural strength and high decorative.
\end{abstract}

\section{Introduction}

Many-tonnage production of plastic packaging and packaging for food, pharmaceutical, perfume, chemical industry, as well as products of technical purpose made of polyethylene terephthalate (PET), with a total production volume of more than 20 million tons per year and a production increase of $4-6 \%$ annually, corresponds to amount of waste of this polymer. PET is resistant to chemical and biological decomposition, PET-waste is able to remain in ecosystems for many tens and even hundreds of years, reducing the quality of life of the population, presenting a real threat to the animal world [1] and the potential environmental hazard through the long-term emission of harmful substances into ecosystems [2].

\footnotetext{
* Corresponding author: fominanani@yandex.ru
} 
The global trend is the transition to a civilized treatment of waste, which consists in preventing or minimizing their formation, and for generated and accumulated waste - in sorting and possibly more complete processing. Modern waste sorting complexes make it possible to isolate plastic from the total volume of debris and to separate it by types.

Complex thermomechanical methods for processing secondary PET (thermoagglomeration, thermogranulation, extrusion), sometimes in combination with filling [3], chemical modification [4-5] or physical influences [6], are aimed at obtaining materials similar to the original (bottles, films, fibers), or new composite materials and products. The analysis of the published studies shows the elaboration of highly specialized technologies, in particular, the methods for processing the PET waste "bottle in a bottle" [7-8], which require high accuracy of compliance with technological parameters.

At the same time, the increasing volumes of PET waste cause the urgency of finding ways to scale them, and in this sense the material-intensive branch of construction materials production is capable of absorbing an unlimited amount of waste. Processing in building products does not require pre-treatment of waste. The use of polymeric waste as binding composite construction materials allows to obtain products with high reliability and durability under difficult operating conditions (paving slabs, curbs, lawn grills, manhole covers, etc.). Composite products based on polymer waste can partially replace high-burn and high-energy building products - cement and ceramic, which gives an additional environmental effect. In the Strategy for the Development of the Construction Materials Industry for the Period to 2020 and Further Prospects until 2030 (Government Order No. $868-\mathrm{r}$ of 10.05.2016), it is pointed out that the level of waste involvement in new production is low and the need to expand the use of PET waste to produce composite building products.

Recycling of PET waste into construction products is proposed in [9-17]. At the same time, modern building materials science presupposes the control of the composition and structure of the material at each scale level, with the production of products with a given set of properties. In this connection, studies are needed to study the composition and structure of the PET waste in the process of thermomechanical processing, as well as the properties of the construction products derived from it, which was the subject of this work.

\section{Materials and Methods}

Primary PET, ground PET wastes (a mixture of clear and colored bottles from carbonated beverages, with a separated lid and label, without washing and cleaning), as well as crushed polymers obtained by thermomechanical processing of these wastes were investigated. The characteristics of the objects of study are presented in Table 1.

The method of infrared (IR) spectroscopy was used to study the chemical structure of the composite element of polymers, as well as to determine the end groups. To track thermal effects and temperature transitions in polymers, differential thermal analysis (DTA) and thermogravimetry (TG) were used.

To assess the construction and technical properties of products obtained on the basis of binders from secondary PET, samples were made:

- according to the first technological variant - by pressing from hot polymer-mineral compositions prepared in a laboratory melting-mixing unit at a temperature of $270^{\circ} \mathrm{C}$, - according to the second technological variant - by pressing a dry mixture of filler and polymer powder, followed by heat treatment in a mold at $270^{\circ} \mathrm{C}$ for 1 hour;

The pressing pressure in the preparation of the samples was $25 \mathrm{MPa}$, the pressure holding was carried out for 2 minutes. As the filler, quartz sand of the fraction 0.16-0.32 $\mathrm{mm}$ was used. The degree of filling of the compositions varied from 50 to $85 \%$ by weight of the composition, the content of the polymer binder in the composition was suitably from 
15 to $50 \%$, respectively. A day after manufacturing, the samples were subjected to tests to determine their technical characteristics. The density (according to Russian State Standard GOST 12730.1), the compressive strength and bending strength (according to Russian State Standard GOST 310.4), water absorption (according to Russian State Standard GOST 12730.3) of the samples were determined.

Table 1. Characteristics of the objects of study

\begin{tabular}{|c|c|c|}
\hline No. & Objects of research & Symbol \\
\hline 1 & Primary PET (film) & PET \\
\hline 2 & $\begin{array}{c}\text { Secondary PET, obtained by grinding PET waste with a knife } \\
\text { shredder to particles of } 0.1 \ldots 5.0 \mathrm{~mm} \text { in size }\end{array}$ & R-PET \\
\hline 3 & $\begin{array}{r}\text { Crushed polymers (particle size } 0.02 \ldots 0.15 \mathrm{~mm} \text { ), obtained by } \\
\text { milling in a ball mill of a cooled mass from the melt of secondary } \\
\text { PET at a temperature of } 270^{\circ} \mathrm{C}, \text { with a slow natural cooling of the } \\
\text { melt in air at a temperature of } 20^{\circ} \mathrm{C}\end{array}$ & R-PET-S \\
\hline 4 & $\begin{array}{c}\text { Crushed polymers (particle sizes } 0.02 \ldots 0.15 \mathrm{~mm} \text { ) obtained by } \\
\text { grinding in a ball mill of cooled and dried pulp from a secondary } \\
\text { PET melt at a temperature of } 270{ }^{\circ} \mathrm{C}, \text { with rapid cooling of the melt } \\
\text { in water at a temperature of } 20^{\circ} \mathrm{C}\end{array}$ & R-PET-R \\
\hline
\end{tabular}

\section{Results and Discussion}

The IR spectra of the samples under study are shown in Figure 1.

It is known that in the region of $1500-700 \mathrm{~cm}^{-1}$ (finger-print area) conformational transitions are reflected on the spectra, in particular, changes in the shape and intensity of certain bands in this region are caused by trans-ghost transformations $-\mathrm{O}-\mathrm{CH}_{2}-\mathrm{CH}_{2}-\mathrm{O}-$ fragments of PET [18-19]. To identify the structural isomers, the absorption bands of the deformation vibrations of the $-\mathrm{CH}_{2}-$ group and valence vibrations of the $\mathrm{C}-\mathrm{O}$ bond were considered in the samples under study.

It can be assumed, that trance-conformations $-\mathrm{O}-\mathrm{CH}_{2}-\mathrm{CH}_{2}-\mathrm{O}-\mathrm{PET}$ fragments are prevail in primary PET, and trance- and gosh-conformations are in R-PET. Molecular transition in trance-conformation is one of the conditions for crystallization of PET, and in amorphous state molecules of PET are in gosh-form, as known [20]. Therefore it is possible to say about a sufficiently high degree of crystallinity of samples of primary PET, less crystallinity of samples of R-PET and products of its remelting. This interpretation conforms with the research data [21], where the increase in intensity of oscillation of trance-conformations in modified films of PET is associated with an increase in the degree of crystallinity and which is in accordance with the data of X-ray diffraction analysis.

On IR spectra of explored samples in the field of intramolecular interactions (1800-1500 $\mathrm{cm}^{-1}$ ) the most interesting is intensive band of stretching vibrations of the carbonyl group, which appears in the sample of primary PET at $1719 \mathrm{~cm}^{-1}$, and in the samples of R-PET, RPET-S, R-PET-R it shifts to area $1725-1722 \mathrm{~cm}^{-1}$. In this case superposition of absorption spectra of carbonyl groups of various origins is possible; superposition of $\mathrm{C}=\mathrm{O}$ terminal carboxyl groups and $\mathrm{C}=\mathrm{O}$ of the ester bond in the polymer macromolecules are possible too. It is known, if hydroxyl group is attached to a carbon atom of the carbonyl group, the oscillation frequency rises [22]. Therefore, it can be assumed that in all samples of secondary PET a certain number of terminal carboxyl groups appear. 


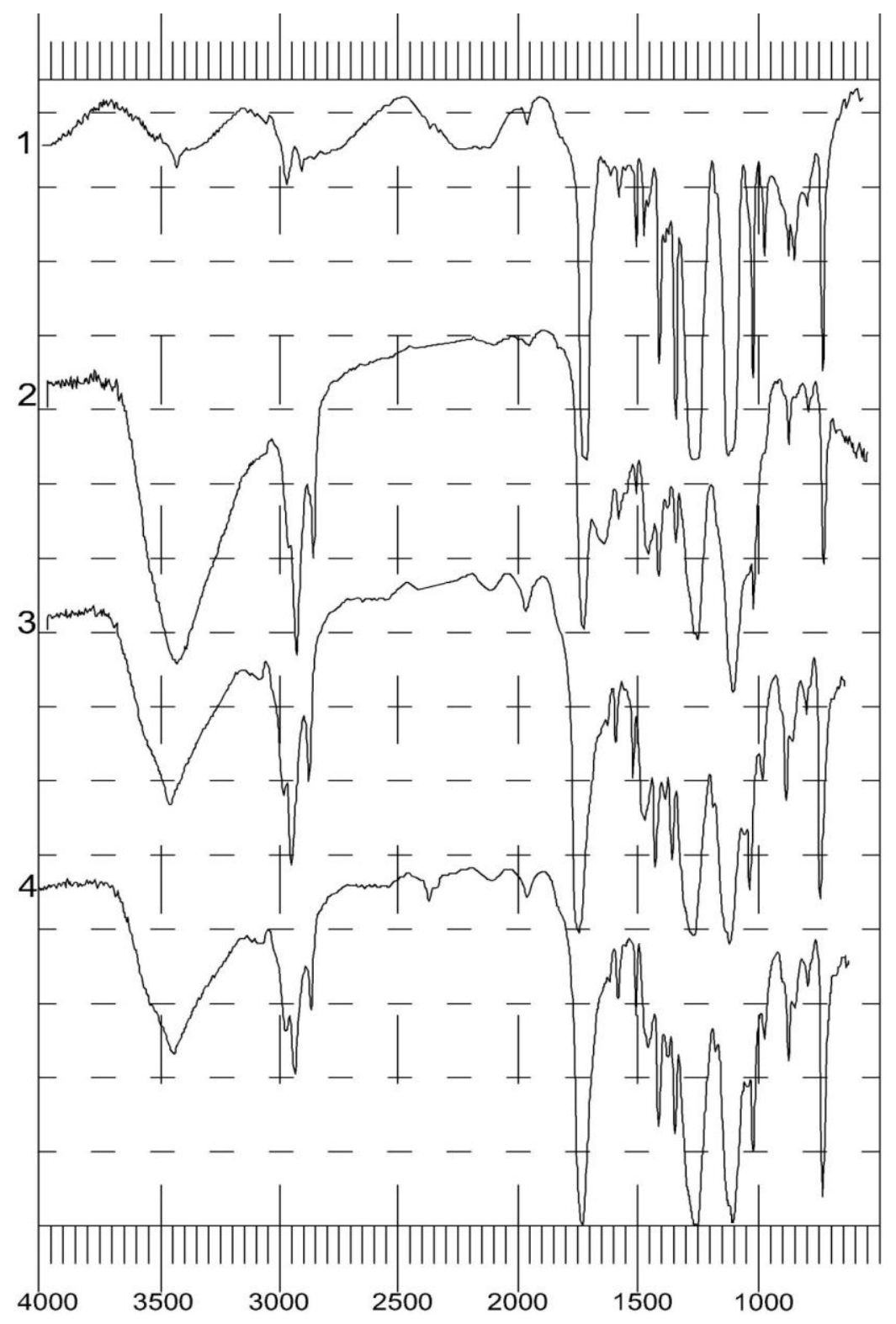

Fig. 1. IR spectra of the samples under study:

1 - primary PET; 2 - R-PET; 3 - R-PET-S; 4 - R-PET-R

IR spectra quantitative processing of the sample of PET shows, that the relative integrated intensity of the absorption of a carbonyl group is stable for samples of R-PET, but it is lower for the sample of PET.

The range $3650-3000 \mathrm{~cm}^{-1}$ of absorption of the hydroxyl group is the most interesting. The relative integrated intensity of the bands of this region is minimal in the sample of the primary PET. In the R-PET sample, the integral intensity is maximal, in the samples of the products of its remelting it is lower, and in the R-PET-R sample, it is lower than in the RPET-S sample. So, the number of terminal hydroxyl groups decreases as a result of thermomechanical processes at processing of secondary PET, probably, it happens due to 
the processes of cross-linking and polycondensation of macromolecules at terminal hydroxyl and carboxyl groups.

Derivatograms and thermograms of the samples are shown in Figure 2.

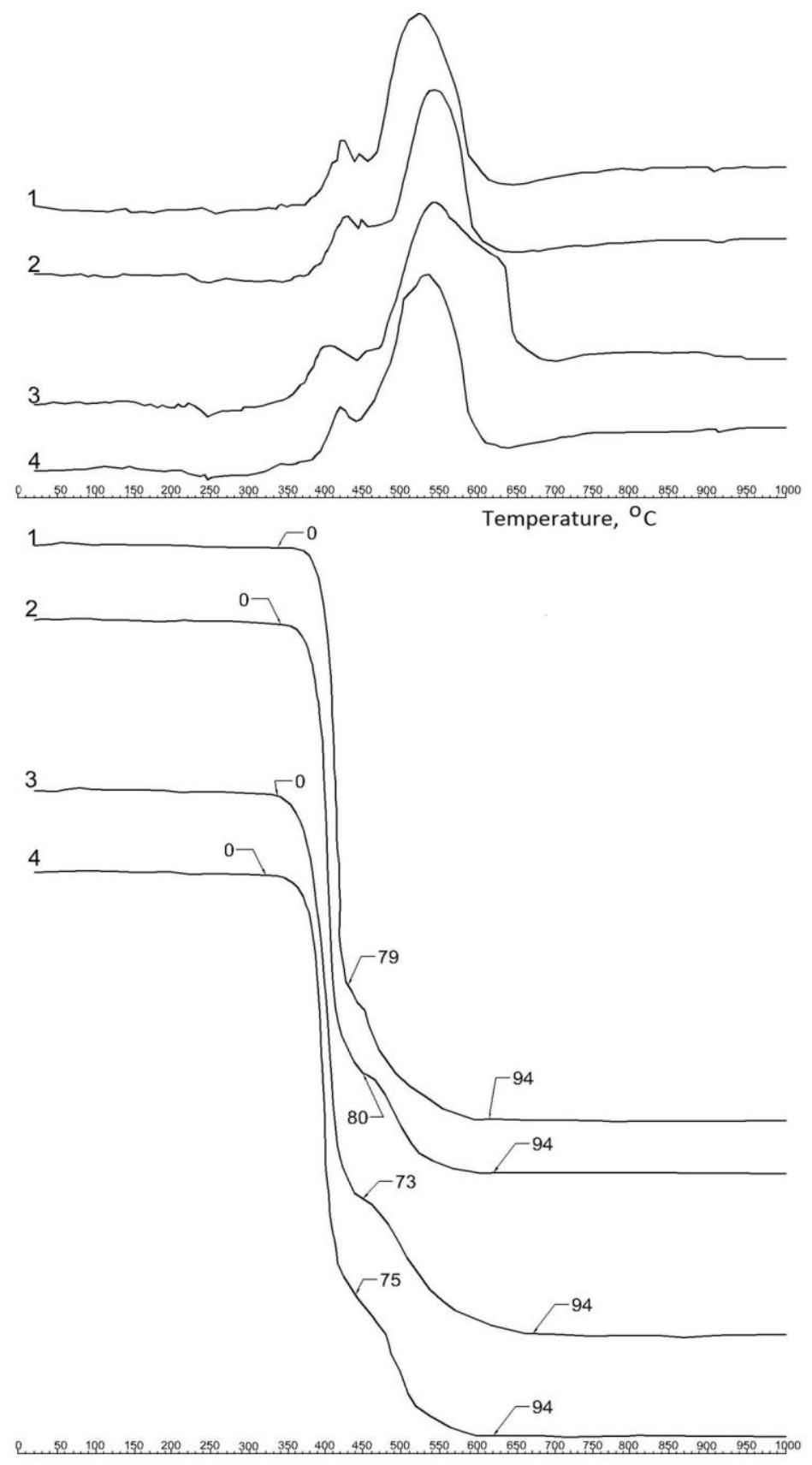

Fig. 2. Derivatograms and Thermograms Curves of the Samples: 1 - primary PET; 2 - R-PET; 3 - RPET-S; 4 - R-PET-R (The thermograms indicated weight loss, \%)

The first stage is characterized by the stability of the mass of all the samples, it is shown by the horizontal stroke of thermograms. A weak endo-effect of melting is recorded on the 
derivatograms. It's worth noticing, in the sample of the primary PET melting begins at 235 ${ }^{\circ} \mathrm{C}$ and the intensity of the endo-effect is the smallest, but in the sample of the R-PET-R melting begins at $210^{\circ} \mathrm{C}$. As the higher temperature of the maxima of endo-effect of melting indicates a more orderly structure [23], it could be assumed the lowest degree of crystallinity of the sample of R-PET-R and it is confirmed by IR spectroscopy data.

The second stage is characterized by intensive loss of mass. The exothermic effect of the thermo-oxidative degradation of the polymer is recorded on the derivatograms. A significant loss in mass is due to the release of gaseous degradation products, the main one is probably primarily acetaldehyde, acid and the product of its decarboxylation [24]. The lowest temperature of the onset of exothermic effect is $320^{\circ} \mathrm{C}$ for the sample of R-PET-R, the maximum is at the temperature $420-430{ }^{\circ} \mathrm{C}$ for all samples. The loss in mass at this stage for samples of primary PET (79\%) and R-PET (80\%) are more, than in products of remelting: $73 \%$ is for the sample of R-PET-S and $75 \%$ for R-PET-R. It tells about greater temperature stability of samples obtained by remelting of secondary PET and confirms IR spectroscopic data on possible crosslinking processes in the polymer during thermomechanical recycling.

The construction and technical properties of the samples prepared from hot mixtures by pressing using R-PET and R-PET-R as a binder are presented in Table 2.

Table 2. The construction and technical properties of the samples prepared from hot mixtures by pressing using R-PET and R-PET-R as a binder

\begin{tabular}{|c|c|c|c|c|c|c|c|c|}
\hline \multirow{2}{*}{$\begin{array}{c}\text { The content of } \\
\text { the binder, } \\
\text { \% by weight of } \\
\text { the composition }\end{array}$} & \multicolumn{2}{|c|}{$\begin{array}{c}\text { Average } \\
\text { density, } \\
\text { kg / m }\end{array}$} & \multicolumn{2}{c|}{$\begin{array}{c}\text { Compressive } \\
\text { strength, MPa }\end{array}$} & \multicolumn{2}{|c|}{$\begin{array}{c}\text { Bending } \\
\text { strength, } \\
\text { MPa }\end{array}$} & \multicolumn{2}{|c|}{$\begin{array}{c}\text { Water } \\
\text { absorption, \% } \\
\text { by weight }\end{array}$} \\
\cline { 2 - 10 } & PET & $\begin{array}{c}\text { RET- } \\
\text { PE }\end{array}$ & $\begin{array}{c}\text { R- } \\
\text { PET }\end{array}$ & $\begin{array}{c}\text { R- } \\
\text { PET- } \\
\text { R }\end{array}$ & $\begin{array}{c}\text { R- } \\
\text { PET }\end{array}$ & $\begin{array}{c}\text { R- } \\
\text { PET- } \\
\text { R }\end{array}$ & $\begin{array}{c}\text { R- } \\
\text { PET }\end{array}$ & $\begin{array}{c}\text { R- } \\
\text { PET- } \\
\text { R }\end{array}$ \\
\hline 15 & 1813 & 1890 & 10.0 & 10.4 & 4.0 & 3.8 & 7.0 & 7.1 \\
\hline 20 & 1935 & 1920 & 22.5 & 21.6 & 5.6 & 4.9 & 2.7 & 3.5 \\
\hline 25 & 1975 & 1979 & 40.5 & 34.4 & 9.2 & 8.3 & 0.8 & 1.1 \\
\hline 30 & 1961 & 1953 & 76.4 & 40.0 & 17.4 & 12.0 & 0.3 & 0.5 \\
\hline 35 & 1890 & 1860 & 69.8 & 47.5 & 14.5 & 12.5 & 0.3 & 0.5 \\
\hline 40 & 1838 & 1838 & 65.8 & 54.6 & 13.9 & 9.6 & 0.3 & 0.2 \\
\hline 50 & 1720 & 1778 & 61.7 & 58.0 & 9.0 & 7.3 & 0.3 & 0.2 \\
\hline
\end{tabular}

From the presented data, one can see, that densities of samples based on secondary PET and based on the product of its remelting (R-PET-R) are close. The highest density is observed at $25 \%$ binder content in the composition. Density reduction with higher degrees of filling indicates a lack of a binder and, as a result, on the formation of a defective structure of the composite.

All the samples have very low water absorption values at $25 \%$ or more of the binder content of the composition, this indicates a potentially high durability of the products.

The dependences of the tensile strength of the samples made on the basis of R-PET are extremal with a maximum at $30 \%$ binder content in the composition. The dependence of the 
bending strength of samples based on the remelting product (R-PET-R) is also extreme with a maximum at $30-35 \%$ binder content in the composition, and the compressive strength increases with increasing content of the binder in the composition.

All in all, strength parameters of the samples produced on the basis of the product of remelting (R-PET-R) are high, but lower than for the samples based on R-PET, especially at the optimal degrees of filling. A lower viscosity of the compositions during the manufacturing of samples based on R-PET-R is noted. All this is a confirmation of the destructive processes during the remelting of polymer waste and indicates the expediency of recycling them in products with a long operating period, such as construction materials.

\section{Conclusions}

1. It is established that, in the process of manufacturing and operation of packaging, packaging, PET articles in the secondary polymer, the number of terminal hydroxyl groups increases, indicating a certain degree of destruction. Thermomechanical processes during re-melting of secondary PET lead to a certain reduction in their quantity due to the possible processes of cross-linking and polycondensation of macromolecules at the terminal hydroxyl and carboxyl groups.

2. In this case, conformational rearrangements take place in the polymer structure: trans-isomers of macromolecules predominate in the primary PET, in the secondary PET trans-isomers are partially present, and to a greater extent - gosh-isomers of macromolecules, which indicates a decrease in the degree of crystallinity of the polymer. The lowest degree of crystallinity of the melted and rapidly cooled secondary PET indicates a potentially advantageous energy state as a binder of composite construction material.

3. Melting of the secondary PET simplifies the process of its grinding, ensuring the production of powdery binders; due to this, the temperature of the beginning of the subsequent melting decreases (approximately $15^{\circ} \mathrm{C}$ ), that allows to reduce power inputs in melting-mixing units in the process of manufacturing construction products. The resistance to destructive decomposition of the polymer at high temperatures is increased.

4. Destructive processes in the remelting of polymer waste cause the expediency of processing waste in products with a long operating period, such as building materials with structural strength and high decorative.

The studies were carried out with the support of an individual grant of the Foundation for the promotion of small enterprises in the scientific and technical sphere within the framework of the program "UMNIK-2017».

\section{References}

1. L. C. M. Lebreton, J. Van Der Zwet, J.-W. Damsteeg, B. Slat, A. Andrady, J.Reisser. Nat. Communications, 8, 15611 (2017)

2. G.T. Armisheva // Vestnik PNIPU. Urbanistika, 4, 64-77 (2011)

3. K. B. Prabhu, G. J. Chomal, S. Mkulkarni. Education and Green Sky - Materials Technology for a Better World: International Technical Conference, 1256-1270 (Long Beach, 2013)

4. Eh. V. Gogol, I. H. Mingazetdinov, G. I. Gumerova, O. S. Egorova, S. A. Malceva, I. G. Grigoreva, Yu. A. Tunakova. Vestnik KNRTU, 16, 10, 163-168 (2013)

5. B. Geyer, S. Röhner, G. Lorenz, A. Kandelbauer. J. Appl. Polym. Sci., 131, 2, 39786 (2014) 
6. S. V. Degtyarev. Napravlennoe modificirovanie svojstv poliehtilentereftalata kompleksnymi soedineniyami hroma (III). PhD dissertation, 135 (Moscow, 2006)

7. J. M. Mendivil-Escalante, J. M. Gomez-Soberon, J. L. Almaral-Sanchez, R. CorralHiguera, S. P. Arredondo-Rea, A. Castro-Beltran, F. G. Cabrera-Covarrubias. Int. J. Structural Analysis \& Design, 2, 1, 105-109 (2015)

8. N. A. Petov. Tverdye bytovye othody, 8, 46-49 (2008)

9. D. A. Beeva, A. K. Mikitaev, E. B. Barokova, A. A. Beev, V. A. Borisov, A. A. Yakokutova. Fundamental research, 10, 2878-2881 (2013)

10. L. A. Bodyan, I. A. Varlamova, H. Ya. Girevaya, N. L. Kalugina, T. A. Girevoj. Modern high technologies, 2, 15-18 (2015)

11. N. N. Fomina, Yu. G. Ivashchenko, M. M. Polyanskij. Patent RU 2623754 (2017, bul. 19)

12. T. C. Blanken, A. K. Van Helden, J. C. J. E. Majoor, H. H. Mooiweer, M. J. Reynhout, W. Wisse. Patent EP 1395527 B1 (2004, bul. 11)

13. V. A. Lukasik, Yu. A. Ancupov, N. V. Sychev, V. P. Medvedev, V. V. Lukyaniches, D. V. Medvedev. Patent RU 2270817 (2006, bul. 6)

14. Yu. A. Ancupov, A. V. Ilin, V. A. Lukasik. Stroitelnye materialy, 1, 44-45 (2004)

15. S. S. Davaasengeh, O. N. Burenina. Izvestia RAS SamSC, 11, 5(2), 276-278 (2009)

16. V. I. Kernickij, N. A. Zhir. Polimernye materialy, 8, 11-21 (2014)

17. N. A. Petov. Polimernye materialy, 4-5, 74-78 (2010)

18. I. Dekhant. Infrakrasnaya spektroskopiya polimerov, 472 (Moscow, Himiya, 1976)

19. A. V. Makarov. Modificirovanie plenok poliehtilentereftalata pod vozdejstviem uskorennyh ehlektronov. PhD dissertation, 135 (Saint-Petersburg, 2010)

20. A. X. Kupcov, G. N. Zhizhin. Fur'e-spektry kombinacionnogo rasseyaniya $i$ infrakrasnogo pogloshcheniya polimerov, 656 (Moscow, FIZMATLIT, 2001)

21. Smit A. Prikladnaya IK-spektroskopiya, 382 (Moscow, Mir, 1982)

22. S. V. Kudashev, U. R. Urmancev, B. V. Tabaev, V. N. Arisova, T. I. Danilenko, V. F. Zheltobryuhov. Izvestia VolgSTU, 11, 19 (122), 86-90 (2013)

23. B. V. Tabaev, R. N. Hlestkin, E. I. Maslennikov. Bashkirskij himicheskij zhurnal, 17, 4, 29-31 (2010)

24. S. Madorskij. Termicheskoe razlozhenie organicheskih polimerov, 328 (Moscow, Mir, 1967) 